\title{
子どもと家族 ＼cjkstart家政学研究連絡委員会の活動から～
}

\section{島田淳子}

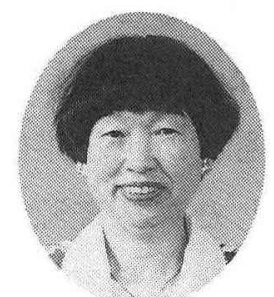

家政学研究連絡委員会（家研連）は、今期 研究テーマとして“家族”を取り上げ活動を 行ってきた。去る平成 8 年12月13日にはシン ポジウム「子どもと家族」を開催してその研 究成果の一部を公開した。現在研究報告書の まとめに向けて作業を進めている。本研連の 活動について、前期までの状況も含めて簡単 に紹介する。

\section{1. 家研連の設立と前期までの活動状況}

家研連は昭和59年（1984年）10月、第12期 の途中に、第 6 部に所属する研連として新設 された。研連委員は 10 名であり、昭和 60 年 3 月に第一回研連委員会が開催された。第13期 における研連所属登録学協会は、（社）日本家 政学会、日本家庭科教育学会、(社) 日本繊維 製品消費科学会の 3 学会であり、現在はこれ に、国際服飾学会、生活経済学会、日本消費 者教育学会、日本調理科学会、日本服飾学会 の 5 学会が加わっている。第13〜15期は林雅 子先生（お茶の水女子大学名誉教授）が会員 を勤められた。

家政学は、人間生活における人と環境の相 互作用について、家庭生活を中心として生活 者の視点から研究する総合科学であり、登録 学協会にも見られるように生活に関連するさ まざまな研究を包含している。しかし、大学 において正式に教育・研究が始められたのは 比較的新しく、1947年（昭和22年）に家政学 系学部学科の設置が認められてからである。 この間の事情については前会員林雅子先生に より本誌の前身である日本学術会議月報に紹 介されている1)。
以来50年、関係者の熱意の中で家政学は成 長してきた。学術会議に家研連が設置された ことは、関係研究者に大きな力を与え、家政 学はさらに大きく発展することになった。家 研連の設置については、当時の副会長藤巻正 生先生（東京大学名誉教授・お茶の水女子大 学名誉教授）のお力に負うところが大きいと 聞いており、家政学の発展に対する氏の貢献 は忘れてはならないであろう。

第13期から第15期までの活動の中で特筆す べきことは「家政学における大学設置基準の 見直し」を行ったことである。激変する社会 に対応できる新しい大学教育を推進する為に 熱心な討論が行われ、その結果は1991年 3 月、 対外報告「家政学における大学教育充実のた めの指針」としてまとめられた。この指針は、 それ以降の家政学系の大学や短大の設置・改 組や充実の指針として広く活用されている。

\section{2. 家政学における国際交流}

家政学の国際的な組織として国際家政学会 (IFHE) があり、アジア地区での家政学交流 はアジア地区家政学会(ARAHE)を通して行 われている。IFHEは1908年に設立され、71力 国の家政学者、および200に及ぶ家政学関係の 協会や団体が加入している学会であり、4 年 毎に世界各地で国際会議を開催している。昨 年バンコクで開催された第18回大会には、家 研連を代表して委員の内藤道子氏（山梨大学

島田 淳子（しまだあつこ 1933年生） 日本学術会議第 6 部幹事、家政学研究連絡委員会委 員長、拈茶の水女子大学生活科学部教授、農学博士 専門：家政学 
教授）が出席した2）。

ARAHE は1983年に設立された。設立に当 たっては日本家政学会が主導的な役割を果た し、その中心になったのは当時の IFHEの副 会長・日本家政学会理事の松島千代野氏 (13・ 14 期研連委員、元共立女子大学教授)である。 増加し続ける地球人口や環境破壊などの問題 が樑刻化している中で、全ての国の一人ひと クが真に賢く生きることはこれらの問題解決 の重要な課題の一つであり、私たちは IFHE と連携しつつ研究と普及を推進している。 1995年にジャカルタで開催された ARAHE の大会には第 16 期研連委員・岩崎芳枝氏（郡 山女子大学教授）が家研連を代表して出席し

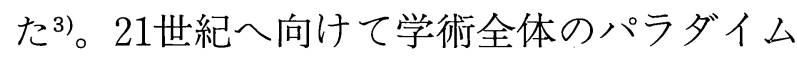
の変換が叫ばれている現在、この会のさらな る発展に向けて日本の果たすべき役割は大き く、かつ重い。

\section{3. 今期の活動およびシンポジウム 「どもと家族」}

今期は「家族に関する研究」を行うことに した。家族の問題は家政学の中で研究すべき 基本的な課題であること、日本家政学会が 1994年の「国際家族年」に向けての研究活動 とその情報提供が高く評価されて国連から表 彰を受けた実績のあること、および、非婚化 や少子化等の家族をめぐる価值観が多様化す る現代社会において家族のあり方についての 再検討が強く求められていることなどが、こ の課題を取り上げた理由である。

子ども、ジェンダー、高齢者、教育などさ まざまな視点から家族に関する研究がなされ
たが、その中から、子どもと家族を取り上げ、 1996年12月13日にシンポジウムを行った。シ ンポジストとタイトルは、1. 牧野カツコ氏 (お茶の水女子大学助教授) 「いま、子ども にとって家族とは」、2 . 小川信子氏 (日本女 子大学教授）「子どもとすまい一子どもか ら見た自分の環境一」、3．足立己幸氏(女子 栄養大学教授）「食は子どもと家族のメッ センジャー」、4. 岡野雅子氏（群馬女子短期 大学教授）「「ごっこ」遊びに現れた家族一 子どもは家族をどう捉えているか一」、 5 ．櫛 田真澄氏（茨城大学教授）「中・高校生の家族 と教育課題」であり、子どもの生活および生 活環境をさまざまな切り口から解析した。会 場には全国から100余名の研究者が集まり熱 心な討論が行われた。この中から現代の子ど もの意識や行動に映し出される家族の抱えて いる諸問題が浮き彫りにされ、その背景にあ る経済性と利便性社会のあり方との関連が整 理された。

今期家研連は本シンポジウムを始め、家族 に関する研究の成果をまとめて報告書とする べく研究を推進中である。

1）林雅子 家政系大学の発足と日本家政学 会 日本学術会議月報第35巻、第 5 号、 P1（平成 6 年 5 月発行）

2 ）内藤道子 21 世紀の生活環境ーグローバ ルな責任と家政学の役割一 第18回国際 家政学会議出席の報告 学術の動向、 1997年 1 月号、P78 80

3 ）岩崎芳枝 アジアでの家政学の交流 学 術の動向、1996年12月号、P59 61 